\title{
The Teaching of Historical Memory as a Tool for Achieving SDG 16 and Teachers' Views on the Exile Memorial Museum (MUME) Routes
}

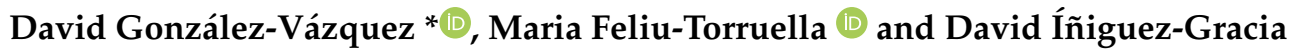 \\ Applied Didactics Department, Faculty of Education, University of Barcelona, 08035 Barcelona, Spain; \\ mfeliu@ub.edu (M.F.-T.); diniguez@ub.edu (D.I.-G.) \\ * Correspondence: david.gonzalez@ub.edu
}

check for

updates

Citation: González-Vázquez, D.; Feliu-Torruella, M.; Íñiguez-Gracia, D. The Teaching of Historical Memory as a Tool for Achieving SDG 16 and Teachers' Views on the Exile Memorial Museum (MUME) Routes. Sustainability 2021, 13, 13637. https://doi.org/10.3390/ su132413637

Academic Editor: John Carman

Received: 19 October 2021

Accepted: 6 December 2021

Published: 9 December 2021

Publisher's Note: MDPI stays neutral with regard to jurisdictional claims in published maps and institutional affiliations.

Copyright: (c) 2021 by the authors. Licensee MDPI, Basel, Switzerland. This article is an open access article distributed under the terms and conditions of the Creative Commons Attribution (CC BY) license (https:/ / creativecommons.org/licenses/by/ $4.0 /)$.

\begin{abstract}
This article analyses the educational role of historical memory in Spain in the context of Education for Sustainable Development and the Sustainable Development Goals. The main objective is to show the utilitarian value of historical memory as an enabling element to achieve SDG 16: "Peace, justice and strong institutions". The study analysed focuses on a very specific heritage product, the exile routes of the Exile Memorial Museum-MUME (La Jonquera, Spain), through a series of semi-open in-depth interviews with teachers who visited the routes. Their responses were crosschecked with the learning objectives for SDG 16 in its three categories: cognitive, socio-emotional and behavioural. The results of this cross-referencing show that there is a significant relationship between the teaching of heritage in places of memory and the block of socioemotional learning objectives, and more specifically with the third category, related to the display of empathy and solidarity.
\end{abstract}

Keywords: Sustainable Development Goals; SDG 16; education for sustainable development; heritage education; places of memory; routes; socio-emotional learning

\section{Introduction}

With the aim of achieving a set of fundamental objectives for the future of humanity, such as eradicating poverty, fighting inequality and injustice and reversing climate change, on 25 September 2015 the United Nations General Assembly approved the document Agenda 2030 for Sustainable Development, with the support of 193 countries [1].

The Agenda 2030 focuses on three dimensions that affect sustainable development: economy, society and environment. In order to ensure its correct and universal implementation, 17 Sustainable Development Goals (SDGs) are deployed, whose mission is to confront the main global challenges, such as the fight against poverty, climate change and education, as well as health, peace, gender equality and sustainable cities [1]

Within the framework of this strategic planning is one of the referential elements of this article, SDG 16 "Peace, justice and strong institutions", the purpose of which is to "promote peaceful and inclusive societies to achieve sustainable development, provide access to justice for all people and develop effective, accountable and inclusive institutions at all levels" [2]. SDG 16 aims to emphasise that only in the framework of peace and respect for fundamental rights, can well-being of people, prosperity of societies, equity of citizenship and sustainable development be achieved, with the underlying idea that the institutions that govern must protect fundamental freedoms and guarantee universal access to justice in conditions of equality at all times.

Since 1992, and therefore prior to the strategic approach of the 2030 Agenda, the United Nations Educational, Scientific and Cultural Organization (UNESCO) has promoted Education for Sustainable Development (ESD), linked to the SDGs since their emergence. Education represents an essential strategy in the achievement of the SDGs, being explicitly formulated in the fourth SDG and strongly related to the rest of the SDGs through various targets and indicators. 
ESD can produce specific cognitive, socio-emotional and behavioural learning outcomes that enable the individual to address the particular challenges of each SDG. Thus, for each of the 17 SDGs, five learning objectives are proposed, within each of the three domains mentioned above. The cognitive domain comprises the knowledge and thinking tools needed to better understand the SDGs and the challenges involved in achieving them. The socio-emotional domain includes the social skills that empower learners to collaborate, negotiate and communicate in order to promote the SDGs, as well as the skills, values, attitudes and incentives for self-reflection that enable them to develop. The behavioural domain describes the competences of each action [3].

Like the SDGs themselves, the learning objectives have a clear universal meaning, allowing these to be adapted into relevant local and regional contexts and, therefore, facilitating their level of impact. Thus, based on this premise, the approach of historical memory has been considered relevant as an important element in the strategic context of education for sustainable development, specifically through SDG 16.

On most occasions, historical memory is understood as a reference to a recent past with a significant traumatic burden linked to violence, repression and other extreme forms of injustice $[4,5]$. Through historical memory, concepts that straddle the legal and political divide are affirmed, such as truth, justice, reparation and guarantees of non-repetition [6,7]. These concepts, therefore, refer to the establishment of peaceful societies where coexistence has taken place after situations of violence and injustice have been experienced in the recent past. There are several political and geographical contexts where this scheme has had an impact, such as South Africa or countries in South America. In the case analysed here, Spain, the issue is more complex, due to the incompleteness and imperfection of the process of applying truth, justice and reparation for the victims of Franco's regime [8-10].

The so-called process of recovery of historical memory in Spain refers to the demand for truth, justice and reparation with respect to the crimes of Francoism, within the chronological framework of the historical stages of the Second Republic, the Civil War, the Franco dictatorship and the transition to democracy (1931-1980) [11,12].

In this context, education plays an important role, since the aforementioned process also has an impact on the improvement of educational tools and strategies in the field of historical memory, representing a major challenge at all levels [13,14]. Likewise, heritage and its different manifestations and educational programmes are projected as an important element in the context of the development of the recovery of historical memory in Spain.

This article presents an analysis of the influence (real and potential) exerted in Spain by historical memory through heritage in the achievement of SDG 16 "Peace, justice and strong institutions". To this end, a process of systematization of experiences [15] was developed on the exile routes, a cultural product that forms part of the educational resources of the Exile Memorial Museum (hereinafter, MUME), in the border town of La Jonquera, Gerona.

\section{Theoretical Framework}

The nature of this study, to analyse the educational impact of historical memory in Spain within SDG 16, makes it necessary to develop a broad, multidisciplinary theoretical framework on which to propose the main conceptual elements that facilitate a correct approach to the study object. Thus, in the following section, various analytical elements will be presented, where the issue of historical memory is analysed from different angles, so that the combination of these elements provides the necessary framework for a critical analysis of the data to be presented later.

We will present the heritage context of the Republican exile places of memory, and the implications of their enhancement process, both as singular spaces and as part of a route. This will be followed by an analysis of the educational context of historical memory in Spain. The different existing legislative implications for the curricular development of historical memory, its role as a tool for the promotion of human rights and the leading role of the emotional factor in the teaching of historical memory through heritage are the key axes on which the aforementioned contextual analysis is based. 


\subsection{The Heritage of Republican Exile: Places and Routes}

The heritage of the Civil War in Catalonia as a testimony of its development is diverse, as the evolution of the conflict turned it into a territory of war, rear-guard action and exile. The Republican exile places of memory are geographically concentrated in the cross-border area Catalonia, covering the easternmost part of the Pyrenees and both sides of the border. Between January and February 1939, the border crossings of La Jonquera, Portbou, Coll d'Ares, Puigcerdà and many others of lesser importance were overwhelmed by the avalanche of people fleeing the military occupation of Franco's army. This human contingent was quantified at almost half a million people [16].

The enhancement of memorial heritage in Catalonia was developed by the institution in charge of the promotion and management of public memory policies, the Memorial Democràtic, created in 2007 [17]. In a context in which democratic memory acquires the category of heritage, and, therefore, the need to be transmitted to new generations $[18,19]$, a comprehensive plan was organised to enhance the value of places of democratic memory in Catalonia [11,12], within which the places of exile had a prominent role.

At legal level, an instrument was developed that made official the existence of a network of memory spaces in Catalonia: the Xarxa d'Espais de Memòria Democràtica [20]. This network structure is divided into four thematic categories, one of which is precisely that of border and exile spaces [21-24]. At the organisational level, it is also structured around three headquarters: the Memorial Democràtic itself in Barcelona and two territorial entities; the Consortium of Memorial Spaces of the Battle of the Ebro (COMEBE) in the south; and the MUME in the north. COMEBE is responsible for the territorial management of the Civil War sites linked to the Battle of the Ebro, while MUME manages the border and exile sites. Although the MUME project precedes the Memorial Democràtic [25], its inauguration took place around the same time and, since then, it has become the catalyst for all the heritage proposals applied to the territory in terms of historical memory [26,27].

On the French side, there are also several initiatives to enhance the heritage of the Republican exile, including the Maternity Hospital in Elne and the memorials of Rivesaltes and Argelès-sur-Mer. These places, together with those south of the border, constitute a cross-border heritage site whose narrative is in most cases shared [28,29], and which have great educational value.

Of all the existing initiatives in the MUME's area of influence, the one that stands out above all is the exile routes promoted by the museum's own educational service [30]. The MUME's exile routes represent a first-rate cultural product in the context of the education of historical memory, due to their history, background, social and educational impact and a vocation for growth and continuity in their relationship with the school world.

In general, the routes are considered to be an important tool for culture, heritage, tourism and education, which facilitates the process of enhancing the value of the existing heritage in different locations. This has been demonstrated in recent years by the general growth in the number of heritage routes on offer [31,32]. The possibility of enhancing and bringing new heritage to the fore makes the routes a tool very much in demand [33], with the capacity to enrich cultural heritage and adjust its possibilities for conservation and enhancement [34]. According to Hernández Ramírez [32], this boom in the routes can be explained by two factors: an increased desire to find authentic experiences and the growing proliferation of new integrated categories, such as landscape or cultural itinerary, promoted by ICOMOS [35].

Through the routes and its capacity to connect and highlight different places, new spaces and heritage categories can emerge. In the case of memorial heritage, which is closely linked to the intangible aspect [36], this makes it an even more relevant issue. In fact, above all other considerations, heritage is not only a driver of development but also an essential tool for discovering our historical memory [37]. As an educational tool that promotes memory, the routes allow students to be physically present and, in the manner of experiential learning, turn that experience into something much deeper than what they 
find in a classroom $[29,30,38,39]$. They also provide an important dynamic element with the capacity to bring the memories of the territory to the surface.

\subsection{Historical Memory and Education: A Utilitarian Relationship}

Rusen [40] argues that memory, or even history as a more elaborate form of memory, aims to preserve the past in order to subsequently use it as a mould for the cultural construction of the present. However, at the educational level, the concept of memory may be considered more appropriate than that of history, since, as Santos [41] points out, the past is significant if it establishes links with present events, which is one of the main defining features of memory [42-45].

For Tribó [4] (p. 9), working and researching in the field of the interrelations between historical memory and education starts from a premise on which there is a broad consensus: "it is necessary to know one's own history in order to build a future based on values of peace and democracy". Historical memory, as a representation of the past in the present, has a utilitarian use.

The study of the past has been approached in this way for decades. According to González [46], the teaching of history in the western world after the Second World War, even without completely abandoning the nationalist vision inherited from nineteenth century education, is based on the transmission of knowledge and skills with the ultimate aim of educating the public to participate actively in democracy. This paradigm is now consolidated, where education about recent history must be aimed at maintaining bridges between the past and present; not as a model to imitate, yearn for or repair, but as a generator of concerns about the present [47].

New paradigms have recently been developed for the analysis of heritage elements linked to historical memory in the educational context, such as the so-called controversial heritage $[48,49]$. Through this vision, it is understood that the different heritage elements to be taken into account in educational contexts have to be classified and analyzed based on their conflictive nature. In the case of places of memory, this nature would be due to an ideological or political character, and its didactic treatment would allow students to approach the development of critical thinking linked to democratic values [50].

In order to aspire to a civic education that fosters democratic values, it is important not to avoid any type of controversial issues, the so-called historical memory being one of the most significant [51]. As Estepa and Delgado [51] state, teaching history through the prism of historical memory encourages critical analysis in those cases where there has been political violence, repression or human rights violations.

The premise of working on historical memory to strengthen the democratic health of contemporary society is particularly relevant in Spain. The Civil War and Franco dictatorship are problematic historical subjects whose education must be tackled in depth, so that their transmission can collaborate with the creation of a democratically aware citizenry [52]. Thus, the appropriate approach to the transmission of knowledge about the period between 1931 and 1975 in Spain should be understood only from the perspective of strengthening young people's democratic values and convictions, and rejecting dictatorships and violent behaviour [53].

\subsubsection{Historical Memory Education in the Spanish Sphere}

The importance of historical memory in the field of education is increasingly important [54]; hence, in the jurisdictional context of Spain's autonomous regions, a legislative approach has gradually consolidated it as a specific educational subject to be included at curricular level.

The concept of Historical Memory in Spain its fairly recent. In 2000, the first scientific exhumation of victims of fascism during the Civil War was carried out in Priaranza del Bierzo (León) and the remains of 13 victims were identified. This was the well-known case of the Priaranza 13. Since then, with the recovery and identification of victims of Franco's regime as the main focus, it is considered the beginning of the so-called process of 
recovery of historical memory $[55,56]$. Together with the exhumations, this process also included initiatives linked to the identification and recovery of places of memory, and the development and implementation of educational approaches for the promotion of historical memory, among others.

In 2007, after several years of public pressure, the Law of Historical Memory [57] was passed in Spain. Although criticised by many for its lack of depth, it laid the legal foundations for working towards a society more aware of the value of its traumatic past as the spearhead of today's democratic values.

Beyond the aforementioned state law, the real impact on issues of historical memory falls to the Autonomous Communities. Thus, in 2007, the Catalan Law [17] came into force and, much later, so did different memory laws from Autonomous Communities: Navarre [58], Basque Country [59], Balearic Islands [60], Andalusia [61], Community of Valencia [62], Aragon [63], Extremadura [64] and Asturias [65].

Despite the fact that the various regional memory laws were expanding their level of real application, with the coverage of the latest ones to be approved being more widespread, analysis of these laws in respect to education shows there is significant scope for improvement for the study of historical memory to have solid legislative support. For example, only the laws passed since 2017 include historical and democratic memory in the curricula. It is worth highlighting, however, the case of the Navarre law, which, although its provisions do not contemplate the inclusion of historical memory in the curriculum, proposes an in-depth review of the curricular content relating to the Civil War and the Franco's regime. Moreover, the Autonomous Community of Navarre has implemented the "Schools with Memory" programme, an educational project for the intergenerational transmission of memory [66].

At the national level, in view of the notorious gap in the Law 52/2007 [57], a new law on historical memory will soon be deployed, whose draft was approved by the Council of Ministers on the 15 October 2020 [67]. Adopting the terminology of "Democratic Memory Law", the new law represents a very significant advancement in terms of truth, justice, reparation and guarantees of non-repetition, introducing a specific prosecutor's office to try the crimes of Francoism and an effective system of penalties. In the field of education, it also represents a notable step forward, by incorporating democratic memory officially into the curricula of Secondary and Higher Education, promoting teacher training in this subject and specifying the educational value of places of memory.

It can be seen, therefore, that with the impetus from different historical memory legislation, it is gradually being included in school curricula, providing a positive context. From now on, however, the challenge this entails is enormous at all levels, but especially for teachers [68].

\subsubsection{Historical Memory as an Instrument Promoting Human Rights}

As has been explained in the previous section, the educational use of historical memory has a utilitarian function that promotes values such as democracy and coexistence. This general vision, however, can be underpinned in a much more specific way, by referring to objectives that are even closer to the legal sphere than the political or educational.

Historical memory in Spain, in its global context, must be understood as a key action of justice to achieve democratic normality [14]. Within this action of justice, education plays a fundamental role, as teaching values such as respect for human rights is more than necessary in a democratic society [69].

One of the most important documents analysing the Spanish human rights situation associated with the memory of its dictatorial past is the report by Pablo de Greiff [70], United Nations Special Rapporteur on the promotion of truth, justice, reparation and guarantees of non-repetition. This report notes the numerous shortcomings in the Spanish political and judicial system for the pursuit of truth, justice, reparation and guarantees of non-repetition, and puts forward a series of recommendations for improvement to build on to achieve these objectives. 
Particularly important are the observations made by de Greiff on the issue of education and historical memory, and how this relationship can help to achieve a present and future of lasting peace and respect for human rights. In section III.C.34, he remarks that "Education is a powerful tool for non-recurrence. In particular the teaching of history, if approached as a system of investigation rather than a mechanism for simply preserving data, can train citizens in habits of analysis and critical reasoning" [70] (p. 9). Thus, he clearly defends a position in favour of the study of the past as a tool for the formation of a critical public with the capacity to consolidate the democratic freedoms won after the dictatorship. Similarly, the report stresses in section III.C.39 that "The Special Rapporteur also wishes to emphasize the fundamental value of human rights teaching as a tool for strengthening guarantees of non-recurrence", and that "The Special Rapporteur insists on the importance of associating the study of the Civil War and Francoism with programmes for human rights training and the promotion of human rights" [70] (p. 10). The message of the report is clear: educating about historical memory favours the promotion of human rights and, therefore, a context of lasting peace and justice.

It is worth mentioning the involvement of another international institution, the Council of Europe, in promoting education in historical memory. The Council of Europe promotes the teaching of memory with the aim of preventing future humanitarian disasters, positioning knowledge of the continent's traumatic past, using the Holocaust as a referential element, the educational basis upon which to build a framework of peaceful and democratic coexistence. It also highlights the importance of places of memory as an evocative element of knowledge with the capacity to connect with school audiences [71]. Through the Council of Europe's approach, we can see a treatment that goes beyond the rhetoric of democratic values to refer to something more concrete and tangible. Working on historical memory at the educational level must serve to educate a public that defends peace, democracy and human rights, and which is aware that it exists today thanks to those people who fought for them in the past [72].

Recovering memory implies confronting the harsh reality of a recent past replete with pain and violence, but it is an act of extreme necessity if the aim is precisely to put an end to the structures that make or have made this violence possible. Such processes, although not free of contradictions, have promoted the establishment of peace and democracy in places as diverse as South Africa, Chile, Argentina and some Central American countries [4]. Educating in memory and, therefore, in human rights, is an essential contribution to the construction of a just, equitable, economically and socially developed nation [73].

\subsubsection{The Emotional Factor in the Education of Places of Memory}

Regarding the study presented here, and in direct relation to the heritage product of reference, the MUME Exile Routes, the following premise is taken as a starting point. Stepping on the ground provides the potential for an in-depth approach to the object of study that cannot be achieved through formal education in a classroom $[29,30,38,39]$. Heritage routes in general, and those of exile in particular, are an important attraction for teachers and students, as they promote strategies to learn from experiences. An experience, senses and emotions are ultimately what makes learning meaningful and make it last.

One of the main features of heritage, which is especially interesting from an educational point of view, is its capacity to generate emotions [74-86]. Heritage can have an impact on the mind, generating diverse sensations and feelings and, therefore, arousing emotions [87,88].

Transferring this capacity of heritage to generate emotion to the educational context raises several interesting points. Firstly, the way in which heritage education facilitates the acquisition of emotional competences [89]: a stage in the evolution of the educational world, where the competence aspect prevails over more traditional visions linked to the acquisition of content, is a factor to be taken into account when planning different curricula as well as the involvement that heritage can have in this development. Secondly, the capacity of heritage to convey a set of social and emotional methodologies for learning 
through experience: this generates a personal commitment and implies that the individuals immersed in the educational process are deeply involved in it [4]. Finally, the relationship between the local scale for working with historical memory and the engendering of diverse feelings: local history is an ideal instrument for working with and understanding the recent past, due to its capacity to promote interest and empathy among students [69].

In its capacity to bring experiences closer, the work with oral sources is a powerful tool within the process of history learning [69]. Moreover, in the same manner that oral sources are recognized for their incalculable value as a historical learning tool and their ability to internalize experiences and forge empathy among students [90], the working field application of those testimonies reflected by oral sources act as a teaching tool for memory transmission. The didactic value contributed by the testimony is high, because it does not explain but shows, and does so without pretending to exemplify anything [91].

Heritage is not heritage if it is not understood as a set of meanings related to personal or collective histories. This is why heritage education strategies can be so closely related to the transmission of emotions and the capacity to move [83]. In fact, neither can it be understood without its facet as an integrating element at a socio-cultural level, forging understanding between past and present societies, and generating empathy between peoples [74].

The specificity of historical memory and the heritage associated with it are important for valuing the use of emotions as an educational strategy [92]. Heritage, in general, should encourage visitors to ask questions and question their own thoughts in order to activate their sensitive and emotional capacity [93]. Memorial heritage, in particular, also follows the same pattern, but with the addition of projecting places and stories related to traumatic experiences and memories. Therefore, places of memory have an enormous educational potential, as well as the capacity to elicit sensory perceptions in students [94,95].

\section{Methodology}

This research is framed within a participatory paradigm, through which a methodology of the systematisation of experiences is applied $[96,97]$ which interprets what happens in a specific educational context, the MUME in this case, in order to systematise and identify good practices.

The main objective of this study is to analyse the potential of the teaching of historical memory through heritage to achieve the sustainable development objective 16 "Peace, justice and strong institutions". To this end, the study was carried out focusing on a highly targeted heritage object, the MUME's Exile Routes, through the implementation of a qualitative research instrument.

In this case, the systematization of experiences seeks to understand an educational process within a heritage context. A process that, despite being flexible according to the diversity of each case, is usually structured in five parts [15]: 1-“The starting point: the experience" that implies having participated in it and having the pertinent records; 2- "Formulate a systematization plan" that implies defining the objective, delimiting the object and specifying the systematization axis; 3 - "The recovery of the lived process" to be able to reconstruct the history of the experience, order and classify the information; 4- "Reflections" to be able to critically interpret and identify learning and finally time; and 5-“The arrival points" that allow us to conclude, recommend and propose new strategies.

The application of the instrument in the first phase of the study allowed access to information of various kinds, such as the categorisation of the exile routes themselves, the evaluation of the educational service provided by the guide on the route, the idiosyncrasy and impact of the materials used and the educational depth of the experience.

\subsection{Research Instrument}

The methodological development of the aforementioned systematization of experiences was based on the existence of a qualitative research instrument, in the form of a semi-open in-depth interview with a structured script, which was applied to a sample of 
teachers who took their students on one of the exile routes. For the design of the instrument, a structure based on a study object, its dimensions, its indicators and the different items on which to have a more direct impact were taken into account. The study object, in this case, was the MUME's exile routes, the product analysed from the perspective of heritage education. Within this object, the dimensions of data and profile, categorisation, educators, materials and educational capacity were taken into account. Each of the dimensions was explored in depth through various indicators, intended to lead to the final items used in questions for the interviewees.

Thus, the script used during the interviews followed a basic structure that comprised the following blocks: teacher profile and their relationship with the routes; categorization and use of routes; usefulness and evaluation of the educational staff in charge of the routes; support materials used on the routes; and educational analysis of the routes. Each block contained various questions, which were adapted to each interviewee depending on the type of responses received.

The research instrument was applied between July and October 2019, on a total of 12 teachers (see Table 1), and the sample selection was based on the number of visits in 2019 between January and June. It should be noted that approximately $80 \%$ of the routes carried out by school groups take place in the months of April, May and June, which is considered to be the high season. A total of 39 schools took part in one of the MUME routes during the aforementioned 6-month period.

Table 1. Selection of teachers interviewed.

\begin{tabular}{cccc}
\hline & \multicolumn{2}{c}{ Teachers Selected for Interview } & \\
\hline TEACHER ID & PROVINCE & YEAR & SUBJECT \\
\hline MZ & Barcelona & ESO & Social Sciences \\
NH & Barcelona & BAT & History \\
MT & Gerona & ESO thics \\
LO & Gerona & BAT & History \\
NA & Barcelona & ESO & Catalan language and literature \\
AS & Gerona & Primary & Social Sciences \\
JB & Gerona & BAT & History \\
JC & Gerona & ESO & Social Sciences \\
TG & Gerona & BAT & History \\
MM & Barcelona & ESO & Social Sciences \\
MB & Barcelona & ESO & Social Sciences \\
OS & Barcelona & BAT & History \\
\hline
\end{tabular}

\subsection{Sample}

The following criteria were taken into account for the selection of the 12 teachers in the sample (Table 1):

Territory: analysis of MUME visitor figures shows that all the study centres that visit the museum and follow one of the routes on offer come from the provinces of Barcelona and Gerona, in a similar percentage (20\% from Barcelona and 19\% from Gerona). Therefore, it was considered that this percentage should also be reflected in the sample $(6 \%$ Barcelona and $6 \%$ Gerona).

School year: The MUME educational service tailors its offer of routes with ESO students (Compulsory Secondary Education, aged between 12 and 15) and BAT students (aged between 16 and 17). To be more specific, the curricular needs of both years determine the study of the issues worked on from the MUME routes (Civil War and exile) in the 4th year of ESO and 2nd year of BAT, via the compulsory subject of History. Analysis of the number of visitors to the museum shows that there is a fairly even split between the groups coming from ESO (19 and from BAT (17), so the sample took this variable into account, and teachers from both years were selected at an approximately equal percentage. Among the 12 teachers selected, there was also a primary school teacher, as some primary school groups (3) have also used the service, although with a much smaller presence. 
Subject: Although the vast majority of teachers involved in the practice of the routes were social sciences teachers, there were several teachers from other disciplines (mainly language, literature and ethics) who consider the MUME exile routes to be a good tool for working with students at the curricular level. For this reason, some teachers of alternative subjects were also selected for the sample.

\section{Results}

There are three learning objectives for SDG 16: cognitive, socio-emotional and behavioural. As mentioned in the methodology section, the different learning objectives for SDG 16 were cross-checked with the interviews conducted with the teachers using the MUME routes, so that it was possible to establish a relatively strong link with some of them.

By way of introduction, it should be said that the level of impact exerted among the three categories of learning objectives has been notoriously uneven. Thus, there is a noticeable influence on the socio-emotional learning objectives, especially the third. However, regarding cognitive learning objectives, hardly any impact has been detected; furthermore, regarding behavioural learning objectives, there is a small link, although not enough to be highlighted.

It was therefore considered appropriate to concentrate the bulk of the analysis on the socio-emotional learning objectives, which can be seen in Table 2. It provides a description of each of the five socioemotional learning objectives, as well as the impact of the exile routes on their achievement according to the teachers interviewed.

Leaving aside the slight impact of objectives 1 and 5, through LO's testimony, the table shows a notable impact of MUME's exile routes on the third socio-emotional learning objective. This is regarding the students' ability to show empathy and solidarity with those who suffer injustice, whether inside or outside their own country. Based on their testimony, 11 teachers out of the 12 interviewed have projected such a relationship.

In structuring the way in which the MUME exile routes have influenced the achievement of socio-emotional learning objective three from SDG 16, five distinct factors have been taken into account: the weather, the value of the use of testimonies, the ability to create personal connections, the overall value of heritage and the routes and the role of educators (see Figure 1).

Table 2. Relationship between the social and emotional learning objectives for SDG 16 and the teacher's view for the MUME exile routes.

\begin{tabular}{|c|c|c|c|c|c|c|c|c|c|c|c|c|}
\hline $\begin{array}{l}\text { SOCIO-EMOTIONAL } \\
\text { OBJECTIVES }\end{array}$ & MZ & NH & MT & LO & NA & AS & JB & JC & TG & MM & MB & OS \\
\hline - Number 1 & & & & $\mathbf{X}$ & & & & & & & & \\
\hline - Number 2 & & & & & & & & & & & & \\
\hline - Number 3 & $X$ & $X$ & $X$ & $X$ & $X$ & $X$ & $X$ & $X$ & $X$ & & $X$ & $X$ \\
\hline - Number 4 & & & & & & & & & & & & \\
\hline \multirow[t]{2}{*}{ - Number 5} & & & & $X$ & & & & & & & & \\
\hline & & & $\mathrm{SOC}$ & D-EM & IONA & OBJEC & ES & & & & & \\
\hline
\end{tabular}

2 Learners are able to discuss local and global issues related to peace, justice, inclusion and strong institutions.

3 Learners are able to show empathy and solidarity for those who suffer injustice, both in their own country and in

4 Learners are able to reflect on a role in local and global issues of peace, justice, inclusion and strong institutions.

5 Learners are able to reflect on the different groups they belonging to (e.g., gender, social, economic, political, ethnic, national, ability and sexual orientation), and their access to justice and a common sense of humanity. 


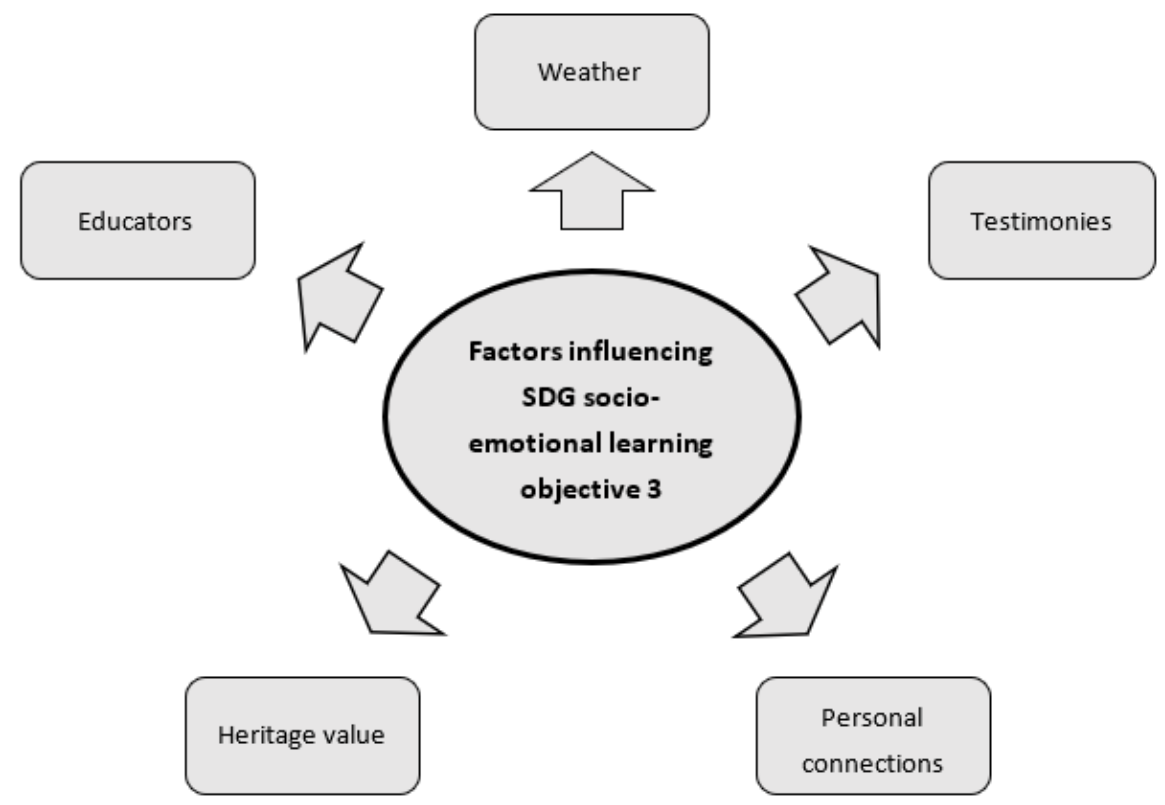

Figure 1. MUME's exile routes factors influencing SDG socio-emotional learning objective number 3.

Regarding weather, it should be said that, despite it being completely alien to the educational approach of the routes, it has become a reference point for some of the teachers who use it. On many occasions, they even try to carry out the activity in the middle of winter, with the aim of experiencing the terrible weather conditions that the exiles had to suffer more than 80 years ago. Experiencing the harsh winter cold for a few hours, even with today's quality warm clothing, is a determining factor in awakening pupils' empathy for the suffering of these people. This was expressed in particular by MZ, NA, JC and TG.

The reading of testimonies along the route is the resource most frequently used. The enormous evocative power and capacity for memorial transmission of the testimonies increase the empathy pupils feel for the people who transmit their testimony, an idea with which MB, JC, MZ and AS agree. The latter, in particular, makes special mention of a testimony with a clear local connection to the territory, which in her opinion multiplies this capacity for empathy on the part of the pupils.

The ability to establish a personal connection between students and the stories presented during the exile routes is also important in relation to learning objective three. The memory of the republican exile is, in many cases, the memory of the great-grandparents of the current generation of ESO and BAT students, and this memory may have been passed down to them through the family. Being able to capture the relationship between one's own family history and the historical content of the route is a determining factor when it comes to engendering empathy in pupils, as stated by NH, MT, and LO.

The element that encompasses the broadest analytical spectrum in conveying a relational analysis between the exile routes and the learning objective number is the impact of stepping on the ground and experiencing the relationship with heritage; and to do so, more specifically, through the realisation of a route. Heritage evokes feelings and sensations that can awaken a capacity for empathy and a sense of solidarity in students. There was a broad consensus among all the teachers interviewed on this point, with teachers $\mathrm{MZ}, \mathrm{NH}, \mathrm{LO}$, NA, AS, TG and MB supporting this argument.

Related to the previous point, it should also be noted that the interviews show a perception that the role of heritage educators is fundamental in fostering empathy and solidarity, playing a complementary role to the teacher and bringing emotion to the learning process, a view shared by $\mathrm{NH}, \mathrm{JB}, \mathrm{JC}$ and TG.

The specificity of places of memory, as heritage that links past and present in a lively and emotional way, enables an empathetic connection both with the suffering of others in the past and with the contexts of injustice in the present. Students in contact with 
the memory of the Republican exile through its spaces and routes are students who are sensitive both to the history of the places visited and to present-day situations that raise parallels with that history. In MB's words, "Visiting these areas where your own people have passed through allows you to understand what happens to other people and this helps the quality of society from an ethical point of view". Working on the approach to the recent past through the prism of historical memory involves a kaleidoscopic vision, in which there is a constant revision of the relationship between past and present. As TG points out, "I don't consider history as a reminder of the past but as a reflection of the present".

\section{Discussion}

The information extracted from the interviews with all the teachers in the study sample was extensive and fruitful, providing relevant data on many of the categories on which the research instrument was structured. In this way, the vision projected by the teachers of the exile routes as an educational element offers multiple ways of connection and dialogue with those contributions existing to date in the field of education, heritage and memory.

In the following, a specific dialectical analysis will be presented with the results extracted in relation to the Socioemotional Learning Objectives for SDG 16 and the MUME exile routes. It can be affirmed that the opinions of the teachers interviewed are largely in line with the bulk of the existing theoretical corpus on the subject of heritage education, as well as its relationship with the emotional question. Similarly, the recognition by the interviewees of the high degree of influence that heritage in general, and the routes as places of memory in particular, exert on educational processes was a notable development.

Starting with this second consideration, which is closely related to the starting premise of the study, we can see how the positive impact and added value of working on historical memory from the point of view of heritage education is a prominent element in the analysis of the interviews. As mentioned above, this study starts from a basic point: the capacity of the routes to have an impact through heritage education, in order to consolidate more significant learning than could be achieved in the classroom. Studies such as that of Roca [38], which analyses urban itineraries in Barcelona, and those of Marquès [49] and Font et al. [29], which focus on the exile routes themselves, confirm this point, while González-Vázquez [30] reinforces this vision in his exhibition study of the MUME's exile routes.

$\mathrm{MZ}$ and $\mathrm{NH}$ highlighted the academic impact when it comes to tackling the entrance exams of their 2nd year BAT students, who could achieve better marks as the subject matter of the exam was covered on the routes. NH also pointed out that what they learn during the experience on the routes will be remembered for the rest of their lives, whereas learning in the classroom is a more routine matter. For their part, LO, NA and MM pointed to the high educational value of the routes, as they help students to understand that they are dealing with a real story: an argument reinforced by AS when he said that the route helps students put themselves in the exiles' own shoes. JC shared a very significant anecdote in this respect, in which a pupil considered to be mediocre excelled in a history exam, having visited the sites of the Battle of Normandy on holiday and having become very involved with the subject.

Prades [90] and Galiana [69] highlight the value of testimonies and oral sources to arouse empathy towards the protagonists. Several teachers spoke about this, highlighting the aforementioned case of AS, in which a letter bequeathed by a local teacher projected a spectacular evocative power on his pupils. $\mathrm{MZ}$ valued the use of testimonies during the route positively, because they give a sentimental touch that attracts the students; while JC valued the capacity they have for making the students put themselves in the role of the testimony itself. MB went a little further in analysing the projection of empathy and emotions by the testimonies, stating that they even help to retain concepts. On the other hand, MM criticised the use of testimonies on the route, not so much for their use as a resource, which he considered appropriate, but for their repetition and abuse. 
Galiana [69] states that working in the field of local history increases the capacity for interest and the possibility of making personal connections. In this sense, LO expressed the importance of being able to connect students and their families with the territory through the places of memory and the routes that go through them, while NH commented that family stories emerged thanks to the routes, which would otherwise have gone unnoticed, and MT highlighted the way in which these family stories that come to light serve as a very powerful educational tool for working with the group.

Another of the premises on which this research is based, supported by the data analysis, is the high impact of heritage on an emotional level and how this influences the teaching and learning processes. Numerous studies have been confirmed this [74-86], as did most of the teachers interviewed. At a general level, AS highlighted the value of heritage as a way to forge emotions that facilitate a connection with students and MB pointed out that they are also useful on an educational level. More specifically, regarding the weather and its influence on pupils, MZ commented that it made an impression, while NA, JC and TG agreed that pupils put themselves in the shoes of the exiles by sharing the difficult sensations caused by the cold and adverse weather. In the same line of analysis, the role played by the heritage educators and their ability to transmit sensations and emotions can be presented. NH and JB agreed in recognising the added value of the educators, precisely because they provide that emotional touch that the teacher lacks, while TG and JC valued their ability to empathise and interact with the pupils.

Finally, it is essential to refer to the very essence of memory, and its identification as past made present [42-45]. This was very much present in TG's testimony, while JB noted the suitability of the theme of exile for establishing this connection between past and present, and agreed with MT, who took advantage of this relationship to work in depth on the theme of the current refugee crises. A final note on the multi-temporal function of historical memory helps to visualise the impact of the study of the past, with the perspective of acquiring ethical and civic values, in the achievement of SDG 16 in terms of the present.

\section{Conclusions}

The main objective of this study was to find out to what extent the implementation of the MUME's exile routes, a non-formal educational activity whose itinerary passes through several places of memory for the Spanish Republican exile, contributes to the achievement of Sustainable Development Goal 16.

The aim of SDG 16 is to acquire "Peace, justice and strong institutions", which is directly related to education in the field of social sciences. Within this great branch of knowledge, we find recent history and memory; the former being understood as the science that studies the past closest to the present day, and the latter as a multidisciplinary approach to the analysis of the impact of the past on the present.

What is known in Spain as historic or democratic memory encompasses elements of both recent history and memory; and its application in schools brings the study of the most traumatic and violent period of the country's recent past closer to children aged between 15 and 17. The Civil War and Franco's regime are historical subjects dealt with in the 4th year of ESO (15 years) and the 2nd year of BAT (17 years); approaching them through the prism of democratic memory facilitates the assimilation of this traumatic past as a necessary element in understanding the importance of the values associated with it: truth, justice, reparation and guarantees of non-repetition.

Approaching the study of the Civil War and Franco's regime with a utilitarian focus on the achievement of these values is interpreted as a key medium- and long-term way to consolidate a model of a just, peaceful society with a democratic background, based on an education that promotes civic-mindedness. In other words, the approach of studying the recent violent past in Spain through historical memory offers an important social tool for the achievement of SDG 16. 
Beyond the obvious relationship between education in historical memory and the achievement of a more just, peaceful and democratically sustainable society, this study establishes that this relationship has a multiplier effect when combined with heritage and non-formal education.

Places of memory constitute a very specific heritage category, whose idiosyncrasies endow them with enormous evocative power. This was confirmed by the vast majority of teachers interviewed in this study, who recognised not only the intrinsic potential of places of memory at an educational level, but also the way in which they arouse emotions in their dialectic relationship with pupils.

The empathy developed by pupils when faced with situations that are alien to their reality, but which currently exist elsewhere, acts as a base on which to start thinking, designing and projecting educational strategies that collaborate in strengthening a context of sustainable development, as understood in the field of Education for Sustainable Development through Socioemotional Learning Objective 3. Through this specific prism, it has been possible to see how the added value of heritage in general, and places of memory in particular, increase the scope of action of this objective. Students who come into contact with places of memory through activities developed through heritage education strategies are able to show empathy with people in the past who endured situations of pain and suffering. The capacity of heritage to build bridges between the past and present makes this possible. But it is possible to go even further in the emotional impact on students, since such empathy is not developed only with regard to the protagonists of the past, but with current situations that raise connections with those traumatic memories of the past, thanks to the evocative power of historical memory and its ability to transfer the past to the present (see Figure 2).

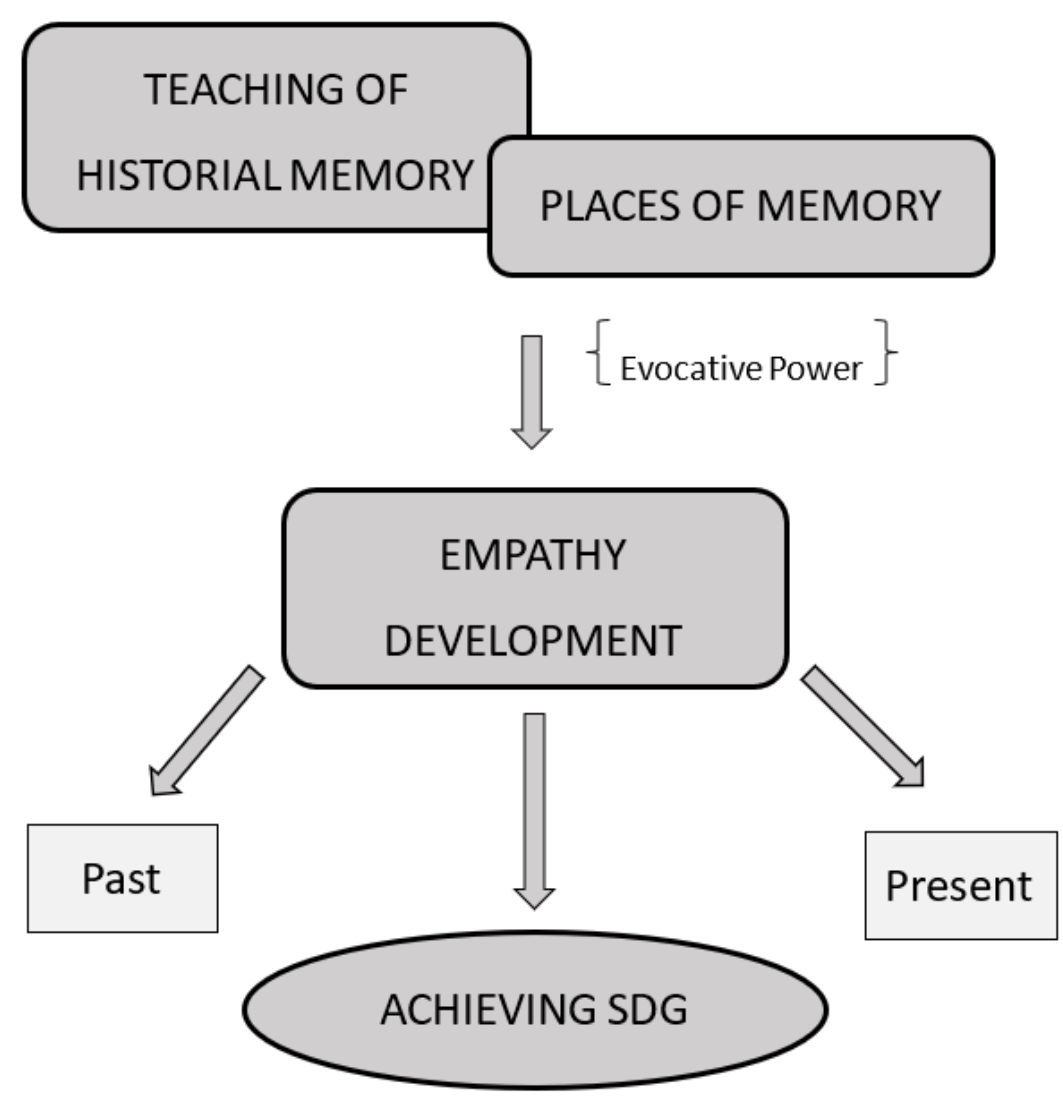

Figure 2. Developing empathy by visiting places of memory as a path to achieve SDG 16 (infography).

In addition to empathising with previous generations, working on the education of the historical memory of the Spanish Republican exile of 80 years ago allows transfers these mechanisms of empathic connection to current cases where similar dramas are unfolding. 
Thus, the teaching of historical memory, and its enhancement through heritage education, is a very valuable tool for the educational approach to the humanitarian and refugee crises that unfortunately still exist today: A comprehensive and integrating vision, projected in line with the spirit of universality raised by the philosophy of the 2030 agenda and the Sustainable Development Goals.

Author Contributions: Conceptualization, D.G.-V. and M.F.-T.; methodology, D.G.-V. and M.F.-T.; formal analysis, D.G.-V. and D.I.-G.; investigation, D.G.-V.; data curation, D.G.-V. and M.F.-T.; writing-original draft preparation, D.G.-V. and D.I.-G.; writing-review and editing, D.G.-V. and M.F.-T. All authors have read and agreed to the published version of the manuscript.

Funding: This research received no external funding.

Institutional Review Board Statement: This study has been approved by the doctoral commission which includes ethics of research such as the adherence to institutional deontological code of good practices in research.

Informed Consent Statement: Informed consent was obtained from all subjects involved in the study.

Data Availability Statement: Not applicable.

Conflicts of Interest: The authors declare no conflict of interest.

\section{References}

1. United Nations. Report of the Secretary-General on the Work of the Organization; UN: New York, NY, USA, 2016.

2. United Nations. Sustainable Development Goals. Available online: https://www.un.org/sustainabledevelopment/sustainabledevelopment-goals/ (accessed on 15 April 2021).

3. UNESCO. Educación Para los Objetivos de Desarrollo Sostenible. Objetivos de Aprendizaje; UNESCO: Paris, France, 2017.

4. Tribó, G.; Fernández, J.; Martínez, L.; Sellés, E. Fem Memòria, Construïm Futur; Graó: Barcelona, Spain, 2010.

5. Escudero, R. Conceptos contra el Olvido: Una guía para no perder la memoria. In Diccionario de Memoria Histórica. Conceptos Contra el Olvido; Escudero Alday, R., Ed.; Los Libros de la Catarata: Madrid, Spain, 2011; pp. 7-14.

6. Chinchón, J. Justicia transicional (La memoria y la lucha contra la impunidad). In Diccionario de Memoria Histórica. Conceptos Hontra el Olvido; Escudero Alday, R., Ed.; Los Libros de la Catarata: Madrid, Spain, 2011; pp. 101-107.

7. López-López, P. Crimenes del franquismo, derecho y justícia transicional. Derecho Y Real. 2015, 13, 131-144. [CrossRef]

8. Escudero Alday, R. Nulidad/ilegitimidad de las sentencias franquistas (Las políticas de la memoria). In Diccionario de Memoria Histórica. Conceptos Contra el Olvido; Escudero Alday, R., Ed.; Los Libros de la Catarata: Madrid, Spain, 2011; pp. 84-89.

9. Escudero, R. Memoria histórica e imperio de la ley: El poder judicial frente el derecho a la reparación de las víctimas del franquismo. Derechos Y Lib. Rev. De Filos. Del Derecho Y Derechos Hum. 2018, 38, 73-105.

10. Martín, J.A. Amnistía (El contexto de la memoria). In Diccionario de Memoria Histórica. Conceptos Contra el Olvido; Escudero Alday, R., Ed.; Los Libros de la Catarata: Madrid, Spain, 2011; pp. 57-63.

11. Guixé, J. El Memorial Democrático y los lugares de la memoria: La recuperación del patrimonio memorial en Cataluña. Entelequia 2008, 7, 217-228.

12. Guixé, J. Espacios, memoria y territorio, un memorial en red en Cataluña. In El Estado y La Memoria: Gobiernos y Ciudadanos Frente a Los Traumas de la Historia; Vinyes, R., Ed.; RBA Libros: Barcelona, Spain, 2009; pp. 569-608.

13. Pagès, J.; Casas, M. Republicans i Republicanes Als Camps de Concentració Nazis. Testimonis i Recursos Didàctics Per a L'Ensenyament Eecundari; Ajuntament de Barcelona-Institut d'Educació: Barcelona, Spain, 2005.

14. Prats, J. Memoria histórica «versus» historia enseñada. Íber Didáctica De Las Cienc. Soc. Geogr. E Hist. 2008, 55, 5-8.

15. Jara, O. La Sistematización de Experiencias: Práctica y Teoría Para Otros Mundos Posibles; Centro Internacional de Educación y Desarrollo Humano-CINDE: Bogotá, Colombia, 2018.

16. Dreyfus-Armand, G. L'éxil Des Republicains Epagnols en France. De la Guerre Civile à la Mort de Franco; Albin Michel: Paris, France, 1999.

17. Llei 13/2007, del 31 d'octubre, del Memorial Democràtic, DOGC 5.006/ 45.172. Available online: https://www.parlament.cat/ document/cataleg/47968.pdf (accessed on 9 December 2021).

18. Vinyes, R. La memoria del Estado. In El Estado y La Memoria: Gobiernos y Ciudadanos Frente a los Traumas de la Historia; Vinyes, R., Ed.; RBA Libros: Barcelona, Spain, 2009; pp. 23-66.

19. Vinyes, R. Memoria, democracia y gestión. História E Perspect. 2016, 54, 11-22.

20. Ordre IRP/91/2010, de 18 de febrer, per la qual es crea la Xarxa d'Espais de Memòria Democràtica de Catalunya, DOGC 5.576/14.651. Available online: https:/ /www.vilanova.cat/doc/doc_35460085.pdf (accessed on 9 December 2021).

21. González-Vázquez, D. La práctica turística como mecanismo de transmisión de valores: Cataluña y los lugares de memoria democrática. Rev. Iberoam. De Tur. RITUR 2014, 4, 36-49. 
22. González-Vázquez, D. La patrimonialización de la memoria histórica: Entre el deber social y la estrategia turística. Apuntes sobre el caso catalán. PASOS Rev. De Patrim. Y Tur. Cult. 2016, 14, 1267-1280. [CrossRef]

23. González-Vázquez, D. El turismo de memoria y las implicaciones de la frontera: Una aproximación teórica desde los Pirineos. In Politiques Memorials, Fronteres i Turisme de Memòria; Arnabat Mata, R., Duch Plana, M., Eds.; PUP/URV Publicacions: Perpinyà/Tarragona, Spain, 2017; pp. 97-114.

24. González-Vázquez, D. Turisme i espais de memòria a la Catalunya transfronterera. REC Rev. D'etnologia De Catalunya 2019, 44, 170-177.

25. Pujol, E. El Museu de l'Exili de La Jonquera. Mnemosine Rev. Catalana de Museol. 2003, 1, 67-78.

26. Font, J. A cavall de la història i la memòria: El Museu Memorial de l'Exili de la Jonquera-MUME. Mnemosine: Revista Catalana de Museologia 2009, 5, 105-113.

27. Font, J. Un equipament amb vocació transfronterera: El Museu Memorial de l'Exili de la Jonquera (MUME). In Euroinstitut Català Transfronterer. Recull de Conferències 2010-2012; Camiade, M., Ed.; Balzac Editeur: Perpinyà, France, 2013; pp. $23-38$.

28. González-Vázquez, D.; Font Agulló, J. La museización del patrimonio memorial transfronterizo: El caso del exilio republicano y sus espacios. Rev. MIDAS-Mus. E Estud. Interdiscip. 2016, 6. [CrossRef]

29. Font Agulló, J.; González-Vázquez, D.; Domènech Casadevall, G.; Marquès Sureda, S. La memoria del exilio republicano a través de sus espacios: Patrimonio, turismo y museos en el territorio catalán transfronterizo. In Lugares de Memoria Traumática. Representaciones Museográficas de Conflictos Políticos y Armados; Arrieta Urtizberea, I., Ed.; UPV/EHU Servicio Editorial: Bilbao, Spain, 2017; pp. 71-98.

30. González-Vázquez, D. Les rutes de l'exili del MUME: Una dècada connectant espais de memòria a la Catalunya transfronterera. EBRE 38 Rev. Int. De La Guerra Civil. 2018, 8, 279-308.

31. López-Guzmán, T.; Sánchez, S. La creación de productos turísticos utilizando rutas enológicas. Pasos Rev. De Tur. Y Patrim. Cult. 2008, 6, 159-171. [CrossRef]

32. Hernández Ramírez, J. Los caminos del patrimonio. Rutas turísticas e itinerarios culturales. Pasos Rev. De Patrim. Y Tur. Cult. 2011, 9, 225-236. [CrossRef]

33. Rengifo, J.I. Rutas culturales y turismo en el contexto espanyol. Boletín Del Inst. Andal. Del Patrim. Histórico 2006, 60, 115-125.

34. Tresserras, J. Rutas e itinerarios culturales en Iberoamérica. Cuad. Del Patrim. Cult. Y Tur. 2005, 15, 13-56.

35. ICOMOS. Carta de Itinerarios Culturales. Comité Científico Internacional de Itinerarios Culturales (CIIC). Quebec: Assemblea General de ICOMOS, 2008, 4th october. Available online: https:/ /www.icomos.org/images/DOCUMENTS/Charters/culturalroutes_ sp.pdf (accessed on 2 May 2021).

36. Roigé, X. De monumentos de piedra a patrimonio inmaterial. Estrategias políticas, museológicas y museográficas de presentación de la memoria. In Lugares de Memoria Traumática. Representaciones Museográficas de Conflictos Políticos y Armados; Arrieta, I., Ed.; UPV /EHU Servicio Editorial: Bilbao, Spain, 2016; pp. 23-47.

37. López Fernández, M.I. Diseño y programación de itinerarios culturales. Boletín Del Inst. Andal. Del Patrim. Histórico 2006, 60, 20-33. [CrossRef]

38. Roca, J. L'itinerari com a forma artística, la ciutat I la ciutadania. In Tourismes. La Serrota de la Sissensió. Itineraris Critics; Fundació Antoni Tàpies: Barcelona, Spain, 2014; pp. 101-113.

39. Marquès, S. Trepitjant història! Una ruta d'exili amb universitaris. Temps I Espais De Memòria. Rev. Digit. Del Meml. Democ. 2014, $2,21-24$.

40. Rüsen, J. Memory, history and the quest for the future. In History Teaching, Identities and Citizenship. European Issues in Children's Identity and Citizenship; Cajani, L., Ed.; Trentham Books Stoke on Trent: London, UK, 2007; pp. 13-34.

41. de Cassia Dos Santos, R. El concepto de pasado reciente en la enseñanza de la historia. Íber Didáctica De Las Cienc. Soc. Geogr. E Hist. 2016, 83, 26-31.

42. Huyssen, A. En Busca del Futuro Perdido. Cultura y Memoria en Tiempos de Globalización; FCE: Ciudad de Mexico, Mexico, 2002.

43. Traverso, E. El Pasado, Instrucciones de Uso: Historia, Memoria, Política; Marcial Pons: Madrid, Spain, 2007.

44. Erll, A. Memory in Culture; Palgrave Macmillan: Basingstoke, UK, 2011.

45. Erll, A. Memoria Colectiva y Culturas del Recuerdo. Estudio Introductorio; Ediciones Uniandes: Bogotá, Colombia, 2012.

46. González, M.P. Memoria, historia reciente y escuela. Notas sobre el caso argentino. Íber Didáctica De Las Cienc. Soc. Geogr. E Hist. 2008, 55, 54-62.

47. Jelin, E.; Lorenz, F.G. Educación y Memoria. La Escuela Elabora el Pasado; Siglo XXI Editores: Madrid, Spain, 2004.

48. Estepa-Gimenez, J.; Martín-Cáceres, M. Competencia en conciencia y expresiones culturales y educación histórica. Patrimonios en conflicto y pensamiento crítico. In La Educación Histórica Ante el Reto de las Competencias. Métodos, Recursos y Enfoques de Enseñanza; Gómez Garrasco, C.J., Miralles, P., Eds.; Octaedro: Barcelona, Spain, 2018; pp. 75-86.

49. Estepa-Gimenez, J.; Martín-Cáceres, M. Heritage in conflict: A way to educate in a Critical and Participative Citizenship. In Handbook of Research on Citizenship and Heritage Education; Delgado-Algarra, E., Cuenca-López, J.M., Eds.; IGI Global: Hershey, PA, USA, 2020; pp. 43-55.

50. Estepa-Gimenez, J. Memoria, patrimonio y ciudadanía: Una contribución desde una perspectiva didáctica. Revista PH 2019, 96, 225-226. [CrossRef] 
51. Estepa-Giménez, J.; Delgado-Algarra, E. Construyendo un compromiso democrático: Memoria histórica, patrimonio y educación ciudadana. In Memoria Histórica y Enseñanza de la Historia; Sáez-Rosenkraz, I., Prats Cuevas, J., Eds.; Trea: Gijón, Spain, 2020; pp. $45-64$.

52. Valls, R.; Parra, D.; Fuertes, C. Los temas históricos conflictivos y su abordaje escolar: Un ejemplo español. Clío Asoc. 2017, 25, 8-21. [CrossRef]

53. Valls Montés, R. La Guerra Civil española y la dictadura franquista: Las dificultades del tratamiento escolar de un tema potencialmente conflictivo. Enseñanza De Las Cienc. Soc. Rev. De Investig. 2007, 6, 61-74.

54. González, P.; Pagès, J. Historia, memoria y enseñanza de la historia: Conceptos, debates y perspectivas europeas y latinoamericanas. Rev. Hist. Y Mem. 2014, 9, 275-311. [CrossRef]

55. Núñez, M. Representaciones de la memoria (Las piezas de la memoria). In Diccionario de Memoria Histórica. Conceptos Contra el Olvido; Escudero Alday, R., Ed.; Los Libros de la Catarata: Madrid, Spain, 2011; pp. 33-39.

56. Silva, E. Movimiento memorialista (El contexto de la memoria). In Diccionario de Memoria Histórica. Conceptos Contra el Olvido; Escudero Alday, R., Ed.; Los Libros de la Catarata: Madrid, Spain, 2011; pp. 69-75.

57. Ley 52/2007, de 26 de diciembre, por la que se reconocen y amplían derechos y se establecen medidas en favor de quienes padecieron persecución o violencia durante la guerra civil o la dictadura. Available online: https://www.boe.es/buscar/pdf/20 07/BOE-A-2007-22296-consolidado.pdf (accessed on 9 December 2021).

58. Ley Foral 33/2013, de 26 de noviembre, de reconocimiento y reparación moral de las ciudadanas y ciudadanos navarros asesinados y víctimas de la represión a raíz del golpe militar de 1936. Available online: https:/ / www.boe.es/eli/es-nc/lf/2013/1 $1 / 26 / 33 /$ dof/spa/pdf (accessed on 9 December 2021).

59. Ley 4/2014, de 27 de noviembre, de creación del Instituto de la Memoria, la Convivencia y los Derechos Humanos. Available online: https://www.boe.es/buscar/pdf/2014/BOE-A-2014-13185-consolidado.pdf (accessed on 9 December 2021).

60. Llei 10/2016, de 13 de juny, per a la recuperació de persones desaparegudes durant la Guerra Civil i el franquisme. Available online: https: / / boe.es/buscar/pdf/2018/BOE-A-2018-6405-consolidado.pdf (accessed on 9 December 2021).

61. Ley 2/2017, de 28 de marzo, de Memoria Histórica y Democrática de Andalucía. Available online: https:/ / www.boe.es/buscar/ pdf/2017/BOE-A-2017-4348-consolidado.pdf (accessed on 9 December 2021).

62. Llei 14/2017, de 10 de novembre, de la Generalitat, de memòria democràtica i per la convivència de la Comunitat Valenciana. Available online: https:/ / www.boe.es/buscar/pdf/2017/BOE-A-2017-15371-consolidado.pdf (accessed on 9 December 2021).

63. Ley 14/2018, de 8 de noviembre, de memoria democrática de Aragón. Available online: https://www.boe.es/buscar/pdf/2019 /BOE-A-2019-466-consolidado.pdf (accessed on 9 December 2021).

64. Ley 1/2019, de 21 de enero, de memoria histórica y democrática de Extremadura. Available online: https://www.boe.es/boe/ dias/2019/02/13/pdfs/BOE-A-2019-1936.pdf (accessed on 9 December 2021).

65. Ley 1/2019, de 1 de marzo, para la recuperación de la memoria democrática en el Principado de Asturias. Available online: https:/ / www.boe.es/buscar/pdf/2019/BOE-A-2019-5480-consolidado.pdf (accessed on 9 December 2021).

66. Layana, C.; Gastón, J.M. Memoria histórica y compromiso institucional: El Instituto Navarro de la Memoria. Studia Histórica 2019, $37,79-106$.

67. Anteproyecto de Ley de Memoria Democrática. Martes 15 de Septiembre de 2020. Available online: https:/ /www.lamoncloa.gob. es/consejodeministros/Paginas/enlaces/150920-enlace-memoria.aspx (accessed on 9 December 2021).

68. Díez Gutiérrez, E.J. La Asignatura Pendiente. La Memoria Histórica y Democrática en Los Libros de Texto Escolares; Plaza y Valdés: Madrid, Spain, 2020.

69. Galiana, V. La memoria democrática en las aulas de secundaria y bachillerato: Balance de una experiencia didáctica. Didáctica De Las Cienc. Exp. Y Soc. 2018, 34, 3-18. [CrossRef]

70. Greyff, D.P. Report of the Special Rapporteur on the promotion of truth, justice, reparation and guarantees of non-Recurrence: Mission to Spain; UN: Geneva, Switzerland, 2014.

71. Pagès, J. El lugar de la memoria en la enseñanza de la historia. Íber Didáctica De Las Cienc. Soc. Geogr. E Hist. 2008, 55, 43-53.

72. Britz, J. Histoire et Mémoire. Éducation à la Prévention Des Crimes Contre L 'Humanité; Conseil de l'Europe: Bruselas, Belgium, 2004.

73. Rosemberg, J.; Kovacic, V. Educación, Memoria y Derechos Humanos: Orientaciones Pedagógicas y Recomendaciones Para Su Enseñanza; Ministerio de Educación: Buenos Aires, Argentina, 2010.

74. Estepa, J. El patrimonio en la didáctica de las ciencias sociales: Obstáculos y propuestas para su tratamiento en el aula. Íber. Didáctica De Las Cienc. Soc. Geogr. E Hist. 2001, 30, 93-105.

75. Lucas, L.; Estepa, J. Educación patrimonial e Inteligencia Emocional. Hablan los alumnos. CLIO. Hist. Hist. Teach. 2017, 43, 194-207.

76. Santacana, J. Museografía didáctica, museos y centros de interpretación del patrimonio. In Museografía Didàctica; Santacana, J., Serrat, N., Eds.; Ariel: Barcelona, Spain, 2007; pp. 395-471.

77. Santacana, J. El patrimonio, la educación y el factor emocional. In Educação Patrimonial: Contributos Para a Construção de Uma Educação Patrimonial; Solé, G., Ed.; CIED Universidade do Minho: Braga, Portugal, 2015; pp. 17-34.

78. Trabajo Rite, M.; Cuenca López, J.M. La educación patrimonial para la adquisición de competencias emocionales y territoriales del alumnado de enseñanza secundaria. Pulso Rev. De Educ. 2017, 40, 159-174.

79. Prades, S. Las fuentes orales en la Educación Secundaria: Motivación y aprendizaje de la Historia. Didáctica De Las Cienc. Exp. Y Soc. 2016, 30, 85-101. [CrossRef]

80. Mèlich, J.C. El trabajo de la memoria o el testimonio como categoría didáctica. Enseñanza De Las Cienc. Soc. 2006, 5, 115-224. 
81. Santacana, J.; Llonch, N. Manual de Didáctica Del Objeto en el Museo; Editorial Trea: Gijón, Spain, 2012.

82. López Benito, V.; Martínez Gil, T. El uso educativo de las emociones en los Museos de la Memoria. HERMUS: Herit. Mus. 2014, 15, 57-65.

83. Pérez, P. La Exposición Sensitiva y Emocional; Editorial Trea: Gijón, Spain, 2012.

84. Saenz del Castillo, A. La arqueología del conflicto en el País Vasco y su potencial didáctico. Rev. Otarq 2017, 2, 129-145. [CrossRef]

85. Feliu-Torroella, M.; Hernàndez-Cardona, F. The Spanish Civil War in the Classrooms: Working for Citizenship Education. In Handbook of Research on Citizenship and Heritage Education; Delgado-Algarra, E., Cuenca-López, J., Eds.; IGI Global: Hershey, PA, USA, 2020; pp. 430-449.

86. Jara, O. Sistematización de experiencias, investigación y evaluación: Aproximaciones desde tres ángulos. Rev. Int. Sobre Investig. En Educ. Glob. Y Para El Desarro. 2012, 1, 56-70.

87. Barbosa-Chacón, J.; Barbosa-Herrera, J.; Rodríguez-Villabona, R. Concepto, enfoque y justificación de la sistematización de experiencias educativas: Una mirada "desde" y "para" el contexto de la formación universitaria. Perf. Educ. 2015, 37, 130-149. [CrossRef]

88. Estepa, J. Investigando las sociedades actuales e históricas. Investig. En La Esc. 2003, 51, 71-82.

89. Estepa, J. (Ed.) La Educación Patrimonial en la Escuela y el Museo: Investigación y Experiencias; UHU Publicaciones: Huelva, Spain, 2013.

90. Fontal, O. La importancia de la dimensión humana en la didáctica del patrimonio. In La Comunicación Global del Patrimonio Cultural; Rusillo, M., Ed.; Trea: Gijón, Spain, 2008; pp. 79-110.

91. Fontal, O. Patrimonio y educación: Una relación por consolidar. Aula de Innovación Educ. 2012, 208, 10-13.

92. Fontal, O. La Educación Patrimonial: Del Patrimonio a Las Personas; Trea: Gijón, Spain, 2013.

93. Coma, L.; Santacana, J. Ciudad Educadora y Patrimonio: Cookbook of Heritage; Trea: Gijón, Spain, 2010.

94. Cuenca, J.M. El papel del patrimonio en los centros educativos: Hacia la socialización patrimonial. Tejuelo 2014, 19 , 76-96.

95. Cuenca, J.M. Escuela, patrimonio y sociedad. La socialización el patrimonio. Rev. UNES Univ. Esc. Y Soc. 2016, 1, $23-41$.

96. González-Sanz, M.; Feliu-Torruella, M. Educación patrimonial e identidad. El papel de los museos en la generación de cohesión social y de vínculos de pertenencia a una comunidad. Clio Hist. Hist. Teach. 2015, 41. Available online: http://clio.rediris.es/n41/ articulos/gonzalezFeliu2015.pdf (accessed on 9 December 2021).

97. Lucas, L.; Estepa, J. El patrimonio como instrumento para la formación de la ciudadanía crítica y participativa. Investig. En La Esc. 2016, 89, 35-46. 